\title{
FERMENTASI BIAK RENDAM MOLASES DENGAN Aspergillus niger UNTUK PRODUKSI ASAM SITRAT
}

\author{
Anne Carolina ${ }^{\mathrm{a}}$, Abubakar Sidik ${ }^{\mathrm{b}}$, Iman P. Maksum ${ }^{\mathrm{b}}$, Saadah D. Rachman ${ }^{\mathrm{b}}$, Agus Safari ${ }^{\mathrm{b}}, \&$ Safri \\ Ishmayana $^{\mathrm{b} *}$ \\ a Departemen Hasil Hutan, Fakultas Kehutanan, Institut Pertanian Bogor, Kampus IPB Dramaga, Bogor 16680 \\ ${ }^{\mathrm{b}}$ Departemen Kimia, Fakultas Matematika dan Ilmu Pengetahuan Alam, Universitas Padjadjaran, Jln. Raya \\ Bandung-Sumedang km. 21, Jatinangor, Sumedang 45363 \\ *Alamat Korespondensi: ishmayana@unpad.ac.id
}

\begin{abstract}
Abstrak: Asam sitrat terdapat melimpah di alam dan dihasilkan sebagai salah satu zat antara pada siklus asam sitrat saat karbohidrat dioksidasi menjadi karbondioksida. Asam sitrat merupakan penyebab rasa asam pada berbagai buah seperti jeruk, nanas dan pir. Karena kelarutannya yang tinggi, rasanya yang enak dan toksisitasnya yang rendah maka asam sitrat banyak digunakan dalam industri makanan, minuman dan obatobatan. Salah satu metode yang digunakan untuk produksi asam sitrat adalah dengan metode fermentasi. Aspergilus niger merupakan salah satu mikroorganisme yang dapat digunakan pada proses produksi asam sitrat. Produksi asam sitrat pada penelitian ini dilakukan dengan tahap pemeliharaan A. niger pada media agar miring, aktivasi kultur $A$. niger dalam inokulum dan produksi asam sitrat dalam media fermentasi yang mengandung 20 , 25, 30 dan 35\% konsentrasi molase dengan metode biak rendam. Analisis yang dilakukan mencakup perubahan $\mathrm{pH}$, berat kering sel, konsumsi gula pereduksi, serta konsentrasi asam sitrat yang dihasilkan. Hasil penelitian ini menunjukkan bahwa asam sitrat paling banyak diproduksi pada media yang mengandung 30\% molase, yaitu diperoleh $85,8 \mathrm{~g} / \mathrm{L}$ asam sitrat.
\end{abstract}

Kata kunci: Aspergillus niger, asam sitrat, molase

Abstract: Citric acid.is naturally present in nature as one of intermediate in citric acid cycle when carbohydrate oxidized to carbondioxide. It is responsible for sour taste in oranges, pineapples, and pear. Because of its high solubility, tasty taste, and very low toxicity, citric acid is widely used in foods, beverages, and medicines industries. One of methods than can be used for citric acid production is fermentation and A. niger is one of the microorganisms than can be used for this purpose. Citric acid production in the present study was conducted through the following steps: growing of A. niger on agar slants, activation of A. niger in inoculums for starter culture, and production of citric acid using fermentation media containing 20, 25, 30 and 35\% of molasses in submerged culture. The product was analysed for its $\mathrm{pH}$, dry cell weight, reducing sugar content and citric acid produced. The results of the present study indicate that the highest citric acid was produced when $30 \%$ molase used resulting $85.8 \mathrm{~g} / \mathrm{L}$ citric acid.

Keywords: Aspergillus niger, citric acid, molases

\section{PENDAHULUAN}

Asam sitrat merupakan salah satu bahan aditif yang dikenal luas pada berbagai kalangan industri, termasuk industri pangan dan farmasi (Soccol et al., 2006; Vandenberghe et al., 1999). Senyawa ini dapat diproduksi dengan memanfaatkan aktivitas mikroorganisme melalui proses fermentasi, baik secara fermentasi padat, biak rendam (Darouneh et al., 2009; Pallares et al., 1996; Manafaati 2011) ataupun dengan menggunakan sel yang teramobilisasi (Demirel et al., 2005).

Banyak mikroorganisme yang dapat digunakan dalam proses produksi asam sitrat, seperti Penicillium glaucum, Candida tropicalis, A. niger, Aspergillus awamori, Aspergillus nidulans, Hansenula anamola dan Yarrowia lipolytica (Max et al., 2010; Soccol et al., 2006; Vandenberghe et al., 1999). Namun, diantara mikroorganisme tersebut $A$. niger merupakan mikroorganisme utama yang digunakan di industri untuk produksi asam sitrat karena menghasilkan lebih banyak asam sitrat per satuan waktu dan juga kemampuannya untuk memproduksi asam sitrat dari bahan yang murah (Soccol et al., 2006).

Molase merupakan hasil samping industri pengolahan gula yang kaya akan kandungan karbohidrat, termasuk sukrosa, glukosa dan fruktosa (Teclu et al., 2009). Karena kandungan karbohdiratnya, maka molase sangat potensial untuk digunakan sebagai sumber karbon pada proses produksi asam sitrat (Darouneh et al., 2009; Ul-Haq et al., 2002).

Pada penelitian ini dilakukan produksi asam sitrat dengan menggunakan substrat molase yang diperoleh dari industri gula PG II Jatitujuh, Majalengka, Jawa Barat dengan menggunakan $A$. niger yang diperoleh dari Labtek-X Institut Teknologi Bandung. Metode fermentasi yang digunakan pada penelitian ini adalah metode biak rendam dengan variasi konsentrasi molase yang ditambahkan ke dalam media fermentasi. 


\section{BAHAN DAN METODE \\ Bahan}

Bahan-bahan yang digunakan pada penelitian ini adalah air suling, asam sitrat standar, asam asetat, tembaga sulfat pentahidrat, dekstrosa (glukosa), feroamonium sulfat, asam klorida, asam oksalat, asam sulfat, kalium dihidrogen fosfat, asam fosfat, kalium ferosianida, mangan sulfat, natrium klorida, natrium hidroksida, amonium sulfat, dan seng sulfat. Kesemua bahan kimia diperoleh dari Merck.

\section{Pembiakan A. niger pada agar miring}

$A$. niger ditumbuhkan pada media agar miring PDA (potato dextrose agar). Sebanyak $200 \mathrm{~g}$ kentang dicuci bersih dan dipotong kecil kemudian direbus dengan $1 \mathrm{~L}$ air suling selama 1 jam. Sebanyak 500 $\mathrm{mL}$ kaldu kentang kemudian disaring kemudian kedalamnya ditambahkan $20 \mathrm{~g}$ glukosa, $15 \mathrm{~g}$ serbuk agar-agar dan diencerkan sampai volume $1 \mathrm{~L}$ dengan air suling. Kemudian dipanaskan sampai larut lalu dimasukkan ke dalam tabung reaksi dan disterilkan dengan autoklaf.

Agar yang telah padat kemudian ditanami dengan $A$. ninger dari stok dan diinkubasi selama 7 hari pada suhu $30^{\circ} \mathrm{C}$ hingga terbentuk spora. Setelah itu disimpan dalam lemari es pada suhu $4^{\circ} \mathrm{C}$ dan siap digunakan untuk pembuatan inokulum spora.

\section{Penjernihan molase}

Sebanyak 200, 250, 300 dan 350 gram molase pekat ditimbang dan dilarutkan dalam $500 \mathrm{~mL}$ air suling, diasamkan dengan asam klorida $4 \mathrm{M}$ sampai pH 4 kemudian ditambah air suling sampai volume 1 L. Hasilnya merupakan larutan molase dengan konsentrasi masing-masing 20, 25, 30 dan 35\% (b/v). Untuk memisahkan pengotor dilakukan sentrifugasi dengan kecepatan $1040 \mathrm{~g}$ selama 30 menit.

\section{Media inokulasi}

Untuk membuat kultur starter, sebanyak satu ose spora $A$. niger dimasukkan secara aseptis ke dalam labu Erlenmeyer yang berisi media cair dengan komposisi 5\% molase, 2,06 g/L ammonium sulfat, $1,2 \mathrm{~g} / \mathrm{L}$ kalium dihidrogen fosfat, $5 \mathrm{ppm}$ tembaga sulfat, $25 \mathrm{ppm}$ feroamonium sulfat, $25 \mathrm{ppm}$ seng sulfat, 25 ppm mangan sulfat, dan 100 ppm kalium ferisianinda. $\mathrm{pH}$ awal diatur dengan penambahan $\mathrm{HCl}$ $1 \mathrm{M}$ atau $\mathrm{NaOH} 1 \mathrm{M}$. Biakan ini dikocok selama dua hari dengan kecepatan $200 \mathrm{rpm}$.

\section{Produksi asam sitrat}

Media fermentasi disiapkan dengan mengambil molase yang telah dijernihkan sesuai dengan konsentrasi yang telah disebutkan sebelumnya. $\mathrm{pH}$ media diatur dengan penambahan asam klorida $4 \mathrm{M}$ sampai mencapai $\mathrm{pH}$ 2. Ke dalam masing-masing larutan dengan konsentrasi molase yang berbeda ditambahkan 2,06 g/L ammonium sulfat, $0,11 \mathrm{~g} / \mathrm{L}$ kalium dihidrogen fosfat, $0,5 \mathrm{~g} / \mathrm{L}$ magnesium sulfat, $0,5 \mathrm{ppb}$ feroamonium sulfat, $20 \mathrm{ppb}$ seng sulfat, 3 ppb mangan sulfat, dan 100 ppm kalium ferisianida.
Media ini kemudian di sterilisasi dengan autoclave. Kultur inokulum diambil secara aseptis sebanyak 5\% (v/v) dan dimasukkan ke dalam media fermentasi, kemudian di kocok dengan kecepatan 200 rpm pada suhu ruang selama 8 hari. Proses fermentasi diikuti dengan memantau perubahan yang terjadi pada media yang meliputi $\mathrm{pH}$, berat kering sel, konsentrasi gula pereduksi dan konsentrasi asam sitrat.

Setiap 24 jam, sampel diambil kemudian ditentukan nilai $\mathrm{pH}$ dengan $\mathrm{pH}$ meter, berat kering sel dengan metode gravimetri dan konsentrasi gula pereduksi yang tersisa pada media dengan metode Somogyi-Nelson (Somogyi 1952; Nelson 1944). Kadar asam sitrat yang dihasilkan pada media ditentukan pada jam ke 144 (Ali et al., 2002) dengan metode KCKT.

\section{Penentuan kadar asam sitrat}

Asam sitrat ditentukan dengan metode KCKT menggunakan kolom nukleosil $10 \quad \mathrm{C} 18$ dengan detektor UV pada panjang gelombang $214 \mathrm{~nm}$. Fasa gerak yang digunakan adalah buffer $\mathrm{KH}_{2} \mathrm{PO}_{4} / \mathrm{H}_{3} \mathrm{PO}_{4}$ $\mathrm{pH}$ 2,4 dengan laju alir 0,8 $\mathrm{mL} / \mathrm{menit}$. Sebelum penentuan standar asam sitrat dan sampel, kolom dicuci dengan mengalirkan metanol $100 \%$, diikuti dengan metanol-air (70:30). Semua fase gerak terlebih dahulu dilakukan degassing selama 30 menit. Konsentrasi standar asam sitrat yang digunakan adalah $10 \mathrm{mg} / \mathrm{L}$ dan sampel disuntikkan ke instrumen setelah disaring dengan saringan milipore $0,45 \mu \mathrm{m}$.

\section{HASIL DAN PEMBAHASAN \\ Pertumbuhan sel $A$. niger}

Waktu optimum inkubasi untuk menghasilkan asam sitrat bervariasi pada setiap organisme dan juga ditentukan oleh kondisi fermentasinya. Menurut Ali et al. (2002), pada fermentasi asam sitrat secara lompok, produksi asam sitrat dimulai setelah fase lag (adaptasi) yang biasanya berlangsung selama 2 hari dan produksi asam sitrat mencapai maksimum pada permulaan fase stasioner atau akhir fase eksponensial (6 hari).

Pada percobaan ini, A. niger ditumbuhkan terlebih dahulu pada media inokulum, sehingga ketika ditumbuhkan pada media fermentasi, fase adaptasinya relatif singkat, atau bahkan ada yang langsung mamasuki fase eksponsial seperti ditunjukkan pada Gambar 1.

Pada konsentrasi molase $20 \% \quad(\mathrm{~b} / \mathrm{v})$ terlihat bahwa A. niger langsung mengalami fase eksponensial dan mencapai puncak pertumbuhan pada jam ke-120, diikuti oleh penurunan berat kering sel yang menandakan memasuki fase kematian pada jam ke-144. Sementara itu, pada konsentrasi molase $25 \%$ (b/v), meskipun sama-sama tidak mengalami fase adaptasi, terlihat bahwa pertumbuhan sel tertinggi dicapai pada jam ke-96, diikuti penurunan berat kering sel pada jam ke-120. Pada variasi 30 dan $35 \%(\mathrm{~b} / \mathrm{v})$ terlihat bahwa fase eksponensial berlangsung sampai jam ke-144, dan setelah itu diikuti oleh penurunan berat kering sel. 


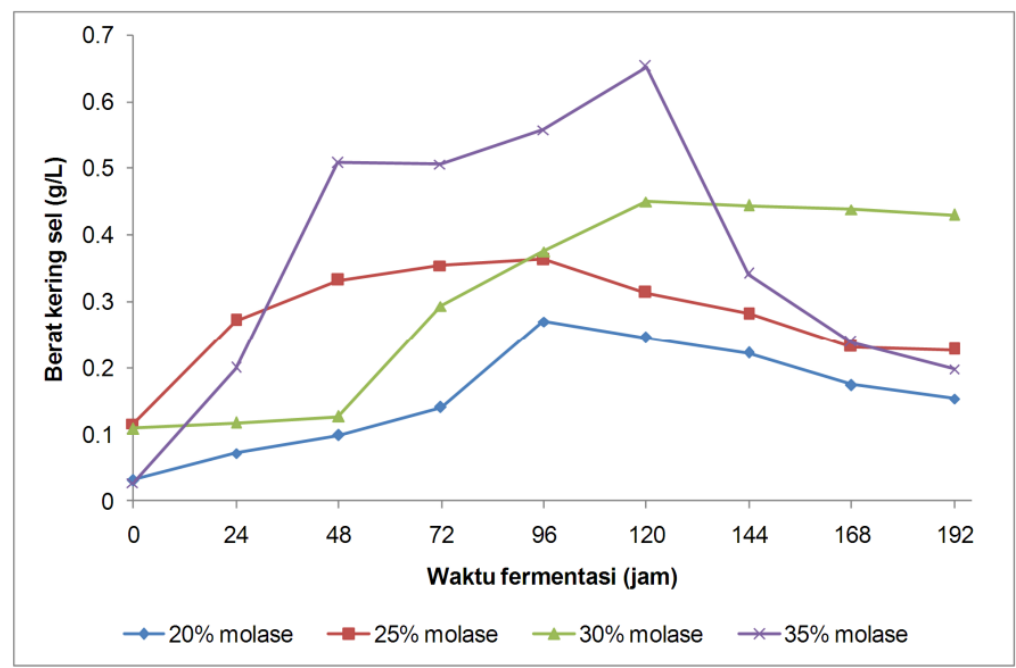

Gambar 1 Kurva pertumbuhan A. niger berdasarkan berat kering sel. Fermentasi dilakukan dengan metode biak rendam dengan kecepatan pengocokan 200 rpm pada suhu kamar.

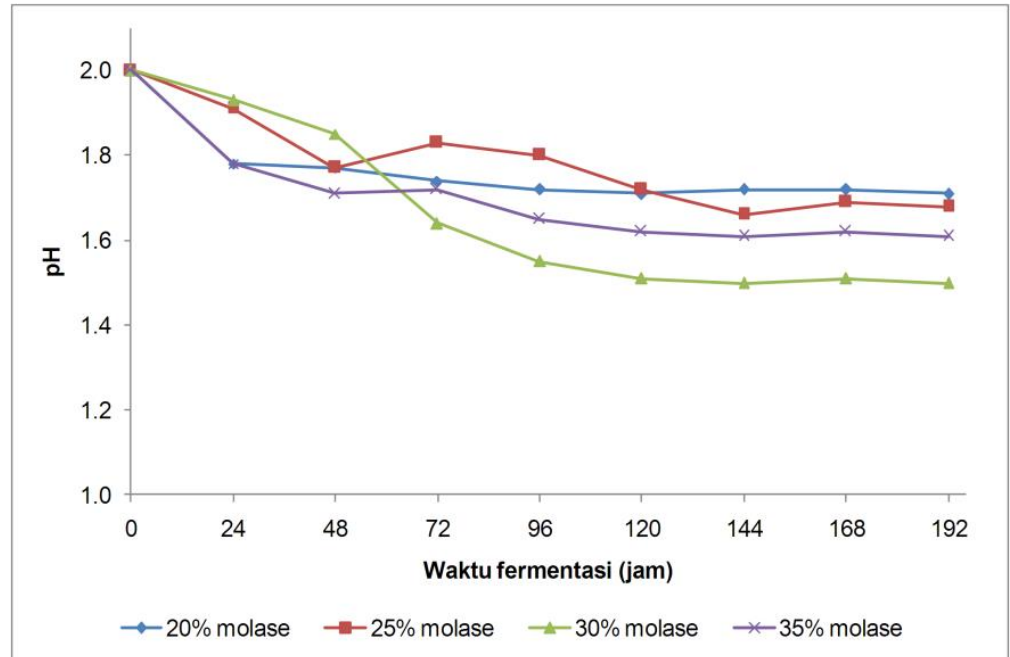

Gambar 2 Perubahan $\mathrm{pH}$ selama proses produksi asam sitrat dengan A. niger. Fermentasi dilakukan dengan metode biak rendam dengan kecepatan pengocokan 200 rpm pada suhu kamar.

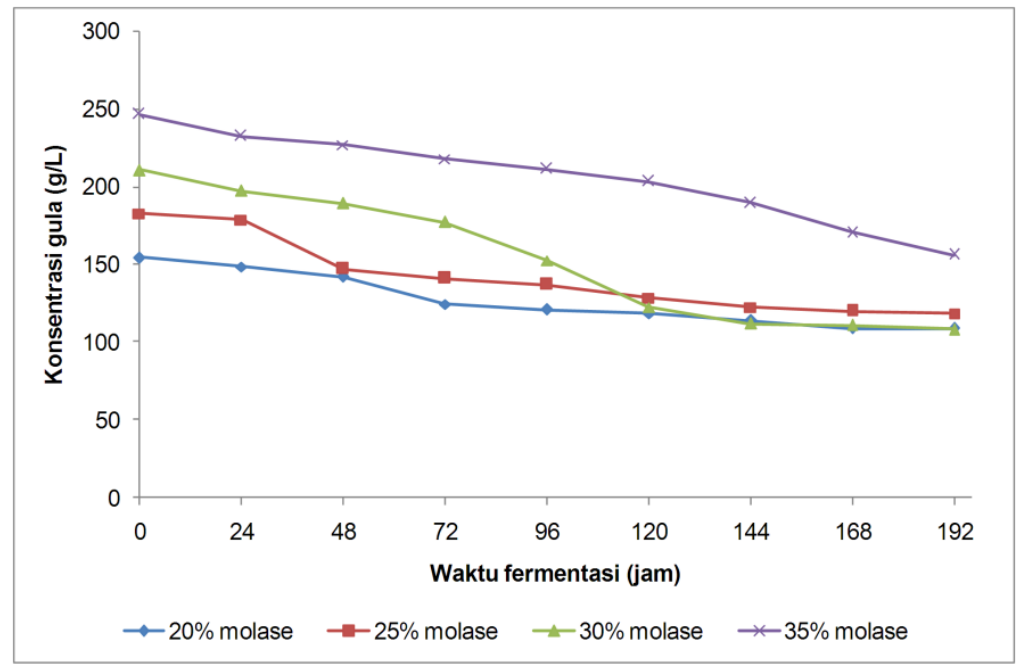

Gambar 3 Perubahan kadar gula pereduksi selama proses produksi asam sitrat dengan A. niger. Fermentasi dilakukan dengan metode biak rendam dengan kecepatan pengocokan 200 rpm pada suhu kamar. 
Hasil pengukuran berat kering sel menunjukkan bahwa konsentrasi gula dapat memengaruhi pertumbuhan sel. Secara umum, konsentrasi gula yang tinggi dapat memicu pertumbuhan sel.

\section{Perubahan pH}

Menurut Poesponegoro \& Liang (1991), proses fermentasi asam sitrat dua tahap memerlukan $\mathrm{pH}$ awal yang rendah untuk merangsang akumulasi asam sitrat. Penerapan $\mathrm{pH}$ awal media yang rendah ini hanya efektif apabila fermentasinya dilakukan dengan proses dua tahap karena $\mathrm{pH}$ rendah cenderung menghambat perkecambahan spora dan pertumbuhan A. niger. Selain itu, Shadafza et al. (1976) juga mengemukakan bahwa $\mathrm{pH}$ awal yang tinggi dapat memicu akumulasi produk lain, yaitu asam oksaloasetat.

Hasil pengukuran $\mathrm{pH}$ media fermentasi ditunjukkan pada Gambar 2. Pada media fermentasi yang mengandung $20 \%(\mathrm{~b} / \mathrm{v})$ molase memperlihatkan perubahan $\mathrm{pH}$ yang terus menurun. Rentang perubahan $\mathrm{pH}$ selama fermentasi dalam waktu 192 jam adalah dari $\mathrm{pH} 2,00 \mathrm{ke} \mathrm{pH} \mathrm{1,71.} \mathrm{Pada} \mathrm{jam} \mathrm{ke-24}$ dan ke-48, $\mathrm{pH}$ media turun dengan cukup tajam dari 2,00 menjadi $\sim 1,78$, namun untuk selanjutnya $\mathrm{pH}$ relatif konstan. Hal ini dimungkinkan terjadi karena adanya aksi penyangga $\mathrm{pH}$ karena adanya asam-asam lemah yang terbentuk yang membentuk buffer dengan garamnya.

Pada variasi konsentrasi molase $25 \%$ (b/v), penurunan $\mathrm{pH}$ terjadi dari 2,00 menjadi $\sim 1,68$. Sedangkan pada konsentrasi molase 30 dan 35\%, terjadi penurunan $\mathrm{pH}$ dari 2 menjadi $\sim 1,51$ dan $\sim 1,61$. Seperti halnya pada variasi molase $20 \%$ (b/v), setelah jam ke-144 nilai $\mathrm{pH}$ semua perlakuan relatif konstan.

\section{Perubahan kadar gula pereduksi}

Gula pereduksi dalam media digunakan oleh $A$. niger sebagai sumber energi untuk pertumbuhan dan aktivitas biokimia lainnya. Semakin besar konsentrasi gula dalam media, maka diharapkan asam sitrat yang terbentuk juga semakin banyak. Hal ini harus ditunjang dengan pengendalian terhadap pertumbuhan sel oleh pembatasan nutrien, terutama oleh logam-logam runut.

Seperti ditunjukkan pada Gambar 3, konsumsi gula pereduksi terbesar teramati pada konsentrasi awal molase $30 \%$ (b/v) yang setara dengan $\sim 246 \mathrm{~g} / \mathrm{L}$ gula pereduksi. Hal ini menunjukkan bahwa semakin tinggi konsentrasi gula pereduksi, maka semakin tinggi tingkat konsumsi gula oleh $A$. niger. Namun kondisi ini terjadi sampai suatu konsentrasi tertentu dimana jika konsentrasi ini terus ditingkatkan, justru akan menurunkan tingkat konsumsi gula pereduksi. Fenomena ini juga teramati pada proses produksi bioetanol dengan menggunakan ragi Saccharomyces cerevisiae, dimana konsentrasi gula yang terlalu tinggi justru menurunkan tingkat konsumsi gula karena adanya cekaman osmotik terhadap sel ragi (Ishmayana et al., 2011).

\section{Produksi asam sitrat}

Penentuan pengaruh konsentrasi gula yang berbeda pada produksi asam sitrat oleh A. niger dilakukan pada konsentrasi molase awal yang berbeda, yaitu 20, 25, 30 dan 35\% yang masingmasing setara dengan 154,50; 182,67; 210,63 dan $246,50 \mathrm{~g} / \mathrm{L}$. Asam sitrat yang dihasilkan diidentifikasi dan ditentukan kadarnya dengan menggunakan kromatografi cair kinerja tinggi (KCKT) dengan kolom nukleosil $10 \mathrm{C} 18$, fasa gerak buffer fosfat $\mathrm{pH}$ 2,4 dan laju alir $0,8 \mathrm{~mL} / \mathrm{menit}$. Detektor yang digunakan adalah detektor UV pada panjang gelombang $214 \mathrm{~nm}$.

Kadar asam sitrat ditentukan pada waktu fermentasi 144 jam. Hasil fermentasi menunjukkan bahwa pada jam ke-144 pH media semua kondisi fermentasi yang diuji sudah mencapai $\mathrm{pH}$ terendah. Selain itu, penelitian yang dilakukan oleh Ali et al. (2002) dan Ul-Haq et al. (2002) juga menemukan bahwa produksi asam sitrat tertinggi diperoleh pada waktu 144 jam. Berdasarkan pertimbangan tersebut, maka sampel pada waktu fermentasi 144 jam diambil dan ditentukan kadar asam sitratnya. Hasil analisis KCKT ditunjukkan pada Tabel 1.

Tabel 1. Hasil penentuan konsentrasi asam sitrat dengan KCKT menggunakan kolom nukleosil $10 \mathrm{C} 18$, fasa gerak

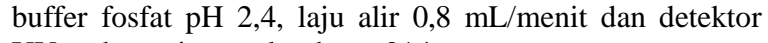
UV pada panjang gelombang $214 \mathrm{~nm}$.

\begin{tabular}{cccc}
\hline $\begin{array}{c}\text { Konsentrasi } \\
\text { molase dalam } \\
\text { media }\end{array}$ & $\begin{array}{c}\text { Waktu } \\
\text { retensi } \\
(\text { menit })\end{array}$ & Luas Area $/ \mathrm{v})$ & $\begin{array}{c}\text { Konsentrasi } \\
\text { Asam sitrat } \\
(\mathrm{g} / \mathrm{L})\end{array}$ \\
\hline Asam sitrat & 5,614 & $1,18 \times 10^{4}$ & 10,00 \\
20 & 5,652 & $3,50 \times 10^{4}$ & 29,57 \\
25 & 5,593 & $7,64 \times 10^{4}$ & 64,55 \\
30 & 5,532 & $9,92 \times 10^{4}$ & 83,79 \\
35 & 5,712 & $2,10 \times 10^{4}$ & 17,76 \\
\hline
\end{tabular}

Keterangan: Asam sitrat adalah standar asam sitrat

Hasil KCKT menunjukkan bahwa konsentrasi asam sitrat yang diproduksi pada media fermentasi dengan konsentrasi molase awal 20, 25, 30 dan 35\% (b/v) masing-masing sebesar 29,57; 64,55; 83,79 dan $17,76 \mathrm{~g} / \mathrm{L}$. Hasil ini menunjukkan bahwa asam sitrat paling tinggi diperoleh pada konsentrasi awal molase $30 \%(\mathrm{~b} / \mathrm{v})$ sesuai dengan data konsumsi gula pereduksi.

Kesesuaian substrat yang tersedia juga mempengaruhi konsentrasi asam sitrat yang terbentuk. Hossain et al. (1984) menemukan bahwa substrat terbaik untuk menghasilkan asam sitrat berturut-turut adalah sukrosa, glukosa, fruktosa dan laktosa. Sedangkan galaktosa tidak menyebabkan terakumulasinya asam sitrat. Molase yang digunakan pada penelitian ini mengandung sukrosa, glukosa dan fruktosa (Teclu et al., 2009), sehingga sesuai untuk digunakan pada proses produksi asam sitrat. 


\section{KESIMPULAN}

Kondisi terbaik untuk produksi asam sitrat dengan metode fermentasi biak rendam adalah dengan menggunakan konsentrasi awal molase $30 \%$ (b/v) yang setara dengan $210,63 \mathrm{~g} / \mathrm{L}$ gula pereduksi. Sebanyak 83,79 g/L asam sitrat dihasilkan dengan kondisi tersebut.

\section{Ucapan Terima Kasih}

Kami mengucapkan terima kasih kepada Bapak U. Djuahria dan Maman Tardi untuk bantuan teknis yang diberikan.

\section{DAFTAR PUSTAKA}

Darouneh, E., Alavi, A., Vosoughi, M., Arjmand, M., Seifkordi, A. \& Rajabi, R. (2009). Citric acid production: Surface culture versus submerged culture, African Journal of Microbiology Research, 3(9), 541-545.

Demirel, G., Yaykaşli, K.O. \& Yaşar, A. (2005). The production of citric acid by using immobilized Aspergillus niger A-9 and investigation of its various effects, Food Chemistry, 89, 393-396.

Hossain, M., Brooks, J.D. \& Maddox, I.S. (1984). The effect of the sugar source on citric acid production by Aspergillus niger, Applied Microbiology and Biotechnology, 19, 393-397.

Ishmayana, S., Learmonth, R.P. \& Kennedy, U.J. (2011). Fermentation performance of the yeast Saccharomyces cerevisiae in media with high sugar concentration, Proceeding of the $2^{\text {nd }}$ International Seminar on Chemistry, Jatinangor, 24 November 2011. pp. 379-385.

Manfaati, R. (2011). Pengaruh komposisi media fermentasi terhadap produksi asam sitrat oleh Aspergillus niger, Jurnal Fluida, 8(1), 23-27.

Max, B., Salgado, J.M., Rodríguez, N., Cortés, S., Converti, A. \& Domínguez, J.M. (2010).
Biotechnological production of citric acid, Brazilian Journal of Microbiology, 41, 862-875.

Nelson, N. (1944). A photometric adaptation of the Somogyi method for the determination of glucose, Journal of Biological Chemistry. 153, 375-380.

Pallares, J., Rodríguez, S. \& Sanromán, A. (1996). Citric acid production in submerged and solid state culture of Aspergillus niger, Bioprocess Engineering, 15, 31-33.

Poesponegoro, M. \& Liang, O.B. (1991). Fermentasi asam sitrat dari tetes tebu secara biak rendam dengan Aspergillus niger, Jurnal Kimia Terapan Indonesia, 1(2), 35-40.

Shadafza, D., Ogawa, T. \& Fazeli, A. (1976). Comparison of citric acid production from beet molasses and date syrup with Aspergillus niger, Jorunal of Fermentation Technology, 54, 67-75.

Soccol, C.R., Vandenberghe, L.P., Rodrígues, C. \& Pandey, A. (2006). New perspective for citric acid production and application, Food Technology and Biotechnology, 44(2), 141-149.

Somogyi, M. (1952). Notes on sugar determination, Journal of Biological Chemistry. 195, 19-23.

Teclu, D., Tivchev, G., Laing, M. \& Wallis, M. (2009). Determination of the elemental composition of molase and its suitability as a carbon source for growth of sulphate-reducing bacteria, Journal of Hazardous Material, 161, 1157-1165.

Ul-Haq, I., Ali, S., Qadeer, M.A. \& Iqbal, J. (2002). Citric acid fermentation by mutant strain of Aspergillus niger GCMC-7 using molase based medium, Electronic Journal of Biotechnology, 5(3), 125-132.

Vandenberghe, L.P., Soccol, C.R., Pandey, A. \& Lebeault, J-M. (1999). Microbial production of citric acid. Brazilian Archives of Biology and Technology, 42(2), 263-276. 